\title{
RANCANG BANGUN MODEL PORTFOLIO BASED ASSESSMENT PADA KOMPETENSI KEJURUAN DI SMK
}

\author{
Tati Abas, Yoyoh Jubaedah, Isma Widiaty \\ Program Studi PKK FPTK UPI \\ J1. Dr. Setiabudhi No. 207 Bandung \\ Email: yoju2010@yahoo.co.id
}

\begin{abstract}
Abstrak: Penelitian ini merupakan studi pengembangan model Portfolio Based Assessment pada kompetensi kejuruan di SMK yang mengacu pada Standar Kompetensi Nasional. Studi pengembangan ini dilakukan dengan menggunakan pendekatan research and development. Tahapan yang dilakukan: (1) Analisis kompetensi kerja berdasarkan tuntutan dunia kerja (stakeholders). (2) Identifikasi karakteristik Portfolio Based Assessment sesuai Standar Kompetensi Nasional. (3) Pengembangan instrumen penilaian berbasis portofolio yang mengacu pada Standar Kompetensi Nasional. (4) Pengembangan kriteria penilaian berbasis portofolio yang mengacu pada Standar Kompetensi Nasional, (5) Merancang desain model Portfolio Based Assessment pada Kompetensi Kejuruan di SMK. Sesuai dengan tahapan penelitian tersebut, menghasilkan luaran sebagai berikut : (a) Model Portfolio Based Assessment pada Kompetensi Kejuruan di SMK. (b) Instrumen Portfolio Based Assessment pada kompetensi kejuruan di SMK.

Kata kunci : kompetensi kejuruan, portfolio based assessment, SMK

Abstract: This study was a development study of Portfolio Based Assessment model in vocational competence in Vocational High School refering to National Competence Standard. This development study was conducted by using research and development approach. The stage it conducted: (1) Work competence analysis based on the demand of stakeholders, (2) Characteristic identification of Portfolio Based Assessment according to National Competence Standard, (3) Development of Portfolio based Assessment instrument refering to National Competence Standard, (4) Development of Portfolio based Assessment criteria refering to National Competence Standard, and (5) Portfolio Based Assessment model in Vocational Competence of SMK. According to such study stages had resulted: (a) Portfolio Based Assessment model design in Vocational Competence of SMK, and (b) Portfolio Based Assessment instrument in vocational competence of SMK.
\end{abstract}

Keywords: Model; Postfolio; Assessment; Vocational Competence; SMK

\section{PENDAHULUAN}

Pendidikan pada Sekolah Menengah Kejuruan program keahlian Tata Busana salah satu tujuannya adalah untuk menghasilkan dan menyiapkan peserta didik untuk menjadi tenaga produktif yang terampil, memiliki daya adaptasi dan daya saing tinggi dalam mengisi peluang kerja di bidang usaha busana. Dalam kenyataannya cukup kontradiktif apabila dikaji dari data pengangguran lulusan SMK pada umumnya, menurut catatan BPS (Kuswari, 2009) di Indonesia angka pengangguran tertinggi berdasarkan pendidikan didominasi oleh lulusan Sekolah Menengah Kejuruan sebesar 17,26 \%, selebihnya SMA (14,31 \%), PT. (12,59\%), 
Diploma $(11,21 \%)$, SMP $(9,39 \%)$ dan lulusan SD $(4,57 \%)$ dari jumlah pengangguran.

Ledakan pengangguran tersebut dapat diminimalisir melalui proses pendidikan yang diselenggarakan di masing-masing SMK, yaitu melalui pengalaman belajar dan penilaian hasil belajar untuk menilai capaian kompetensi peserta didik. Penilaian yang dilakukan harus mampu menggambarkan kemajuan kinerja setiap peserta didik sesuai level kualifikasi yang telah dirumuskan dalam Standar Kompetensi Nasional (SKN) yang dikembangkan oleh praktisi dari dunia usaha dan dunia industri.

Fenomena yang terjadi di lapangan pada umumnya para guru belum menggunakan model penilaian yang mengakomodasi alat penilaian yang mengacu pada tuntutan dunia usaha dan dunia industri. Alat penilaian yang dirancang dan digunakan oleh para guru dalam menilai capaian kompetensi peserta didik masih heterogen pada setiap SMK, sehingga diperlukan alat penilaian yang mengacu pada tuntutan Standar Kompetensi Nasional (SKN). Kondisi ini diperkuat oleh hasil penelitian yang disarikan dari Jubaedah (2005 : 134) yang berkaitan dengan implementasi Competency Based Training berdasarkan Standar Kompetensi Nasional pada kegiatan KBM di SMK, menyimpulkan bahawa: Guru paket keakhlian Tata Busana belum siap untuk mekaksanakan penilaian secara komprehensif pada keberhasilan belajar peserta didik, baik dari kemampuan kognitif, afektif maupun psikomotorik dalam pembuatan busana. Ketidak siapan tersebut teramati dari cara guru dalam melakukan penilaian di dalam kegiatan praktikum, khususnya pada penilaian proses kerja yang belum menggunakan alat penilaian yang sesuai dengan tuntutan Standar Kompetensi Nasional. Departemen Pendidikan Nasional (2006 : 1) menjelaskan bahwa : "Pendekatan yang digunakan dalam pengembangan dan pelaksanaan kurikulum sangat berpengaruh terhadap sistem penilaian yang dilaksanakan".

Penilaian hasil belajar peserta didik di SMK pada dasarnya merupakan bagian integral dari proses pembelajaran, yang perlu diarahkan untuk menilai kinerja peserta didik dengan memantau proses, kemajuan dan perbaikan hasil belajarnya secara berkesinambungan. Pelaksanaan penilaian dapat dilakukan secara langsung pada saat peserta didik melakukan aktivitas belajar, maupun 
secara tidak langsung melalui bukti hasil belajar sesuai dengan kriteria kinerja atau performance criteria. Oleh karena itu sistem penilaian untuk kelompok mata pelajaran produktif pada kompetensi kejuruan dapat mengembangkan model Portfolio Based Assessment.

Pelaksanaan penilaian hasil belajar berbasis fortofolio diarahkan untuk mengukur dan menilai performansi peserta didik dalam kemampuan kognitif, psikomotor dan afektif, melalui bukti hasil belajar (evidence of learning) sesuai dengan kriteria kinerja (performance criteria), yaitu sesuai dengan tuntutan dunia usaha dan industri yang telah dirumuskan dalam Standar Kompetensi Nasional yang melibatkan pihak-pihak terkait dengan pembinaan SMK (stakeholders), karena pada akhirnya kompetensi yang telah dikuasai oleh peserta didik harus mendapat pengakuan dari pihak pemakai tenaga kerja.

Permasalahan penting yang perlu diupayakan jawaban pemecahannya adalah bagaimana merancang bangun model portfolio based assessment pada kompetensi kejuruan di SMK, khususnya pada kompetensi menggambar dan membuat pola busana dengan teknik konstruksi yang sejalan dengan tuntutan dunia usaha dan industri bidang busana.

\section{METODE}

Penelitian ini menggunakan pendekatan Research and Development, meliputi tahap studi pendahuluan dan studi pengembangan model. Studi pengembangan ini berkaitan dengan model Portfolio Based Assessment pada kompetensi kejuruan di SMK yang sesuai dengan Standar Kompetensi Nasional.

Penelitian dilaksanakan pada beberapa SMK Kelompok Pariwisata di wilayah Kota dan Kabupaten Bandung yang mengembangkan program Keahlian Tata Busana. Dari masing-masing SMK melibatkan sejumlah subjek, yaitu guru program produktif dan peserta didik program keahlian Tata Busana kelas XI. Lokasi dan subjek penelitian ditetapkan secara purposive, dengan mempertimbangkan tahap-tahap penelitian serta tujuan khusus penelitian.

Daftar lokasi penelitian yang dijadikan tempat pengembangan model sebagai berikut : SMK Negeri 9 Bandung, SMK N 2 Baleendah Kabupaten Bandung, SMK BPP Bandung, dan SMK R.A Kartini Bandung. 
Instrumen penelitian yang digunakan dalam penelitian ini mengacu pada tahapan pendekatan penelitian Research and Development (R\&D), sehingga dikembangkan intrumen penelitian sebagai berikut: Pedoman Studi Dokumentasi, Pedoman Wawancara, dan Intrumen Penilaian.

Langkah-langkah kegiatan penelitian digambarkan sesuai prosedur sebagai berikut.

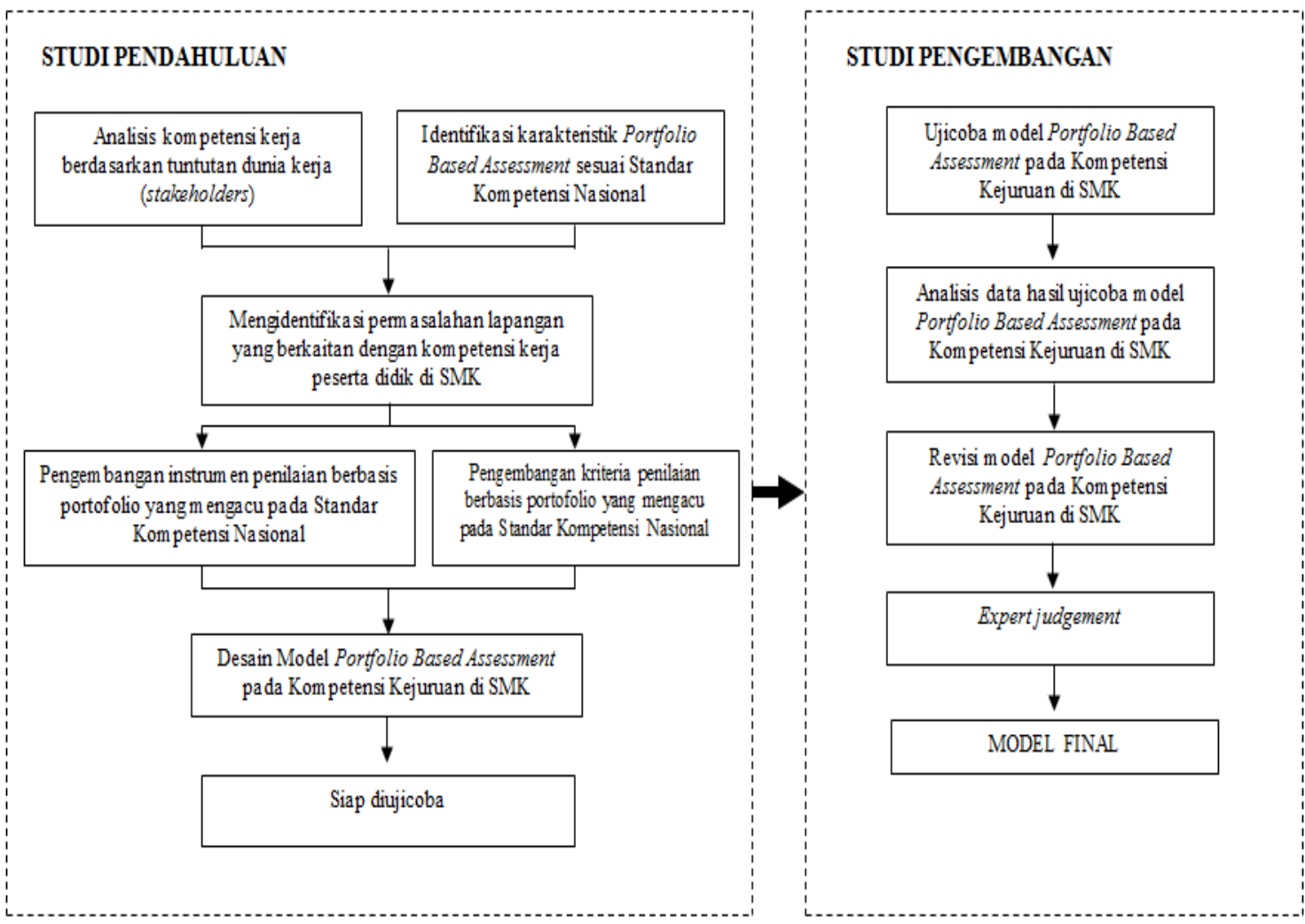

Gambar 1. Langkah-langkah penelitian

\section{HASIL PENELITIAN}

\section{Studi Pendahuluan}

Mata pelajaran kompetensi kejuruan keahlian Tata Busana pada struktur Kurikulum Tingkat Satuan Pendidikan Program Keahlian Tata Busana, secara spesifik bertujuan untuk membekali peserta didik dengan keterampilan, pengetahuan, dan sikap agar kompeten dalam :

1) Mengukur, membuat pola, menjahit dan menyelesaikan busana

2) Memilih bahan tekstil dan bahan pembantu secara tepat

3) Menggambar macam-macam busana sesuai kesempatan 
4) Menghias busana sesuai desain

5) Mengelola usaha di bidang busana

Mata pelajaran kejuruan dikelompokkan pada kelompok produktif, yaitu kelompok mata diklat yang berfungsi membekali peserta didik agar memiliki kompetensi kerja sesuai Standar Kompetensi Nasional (SKN). Kelompok produktif program keahlian Tata Busana terdiri dari kompetensi :

1) Memberikan pelayanan prima,

2) Melakukan pekerjaan dalam lingkungan sosial,

3) Mengikuti prosedur K3,

4) Mengukur tubuh,

5) Menggambar busana,

6) Memilih/membeli bahan baku busana,

7) Membuat pola busana teknik konstruksi,

8) Melakukan pengepresan, (9) Menjahit dengan mesin,

9) Menyelesaikan busana dengan jahitan tangan,

10) Membuat hiasan busana,

11) Melakukan penyelesaian akhir busana,

12) Memelihara alat jahit,

13) Memotong bahan,

14) Membuat pola busana konstruksi di atas kain,

15) Membuat pola busana teknik kombinasi,

16) Membuat pola dasar teknik drapping.

Penilaian produk desain busana dan pola konstruksi sudah menerapkan penilaian berbasis portofolio melalui penilaian dokumen desain sebagai kumpulan tugas pada standar kompetensi Menggambar Busana dan penilaian dokumen pola konstruksi sebagai tugas pada standar kompetensi Membuat Pola dengan Teknik Konstruksi.

\section{Pengembangan Model}

Model Portfolio Based Assessment pada penilaian produk desain busana dan pola konstruksi pada mata pelajaran kejuruan yang sesuai dengan tuntutan Standar Kompetensi Nasional mengadaptasi model penilaian keahlian tata busana 
yang dikembangkan Jubaedah (2009). Melalui Research and Development

dihasilkan pedoman Portfolio Based Assessment sebagai berikut.

PEDOMAN PENILAIAN PORTOFOLIO MENGGAMBAR BUSANA

\begin{tabular}{|c|c|c|c|}
\hline Kompetensi & $\begin{array}{c}\text { Aspek yang } \\
\text { Dinilai }\end{array}$ & Kriteria Penilaian & Skor \\
\hline \multirow[t]{3}{*}{$\begin{array}{l}\text { 1. Mendesain } \\
\text { Busana }\end{array}$} & $\begin{array}{l}\text { a. Memindahkan } \\
\text { gambar busana } \\
\text { di atas proporsi } \\
\text { tubuh }\end{array}$ & $\begin{array}{l}\text { - Apabila memindahkan gambar busana pada } \\
\text { proporsi tubuh sangat tepat memiliki } 5 \text { kriteria, } \\
\text { yaitu : } \\
\text { (1) Sesuai dengan pose tubuh } \\
\text { (2) Detail busana digambar dengan jelas } \\
\text { (3) Adanya garis lipatan kain pada gambar } \\
\text { busana } \\
\text { (4) Melengkapi gambar busana dengan lengkap } \\
\text { (wajah, rambut, asesories) } \\
\text { (5) Menerapkan dasar estetika. } \\
\text { - Apabila memidahkan gambar busana pada } \\
\text { proporsi tubuh tepat, memenuhi } 4 \text { kriteria di atas. } \\
\text { - Apabila memindahkan gambar busana pada } \\
\text { proporsi cukup tepat memenuhi } 3 \text { kriteria di atas. } \\
\text { - Apabila memindahkan gambar busana pada } \\
\text { proporsi gambar busana pada proporsi kurang } \\
\text { tepat memenuhi } 2 \text { kriteria di atas. } \\
\text { - Apabila memindahkan gambar busana pada } \\
\text { proporsi gambar busana pada proporsi sangat } \\
\text { kurang tepat hanya memenuhi } 1 \text { kriteria di atas. }\end{array}$ & $\begin{array}{l}3 \\
2\end{array}$ \\
\hline & $\begin{array}{ll}\text { b. } & \text { Menerapkan } \\
\text { unsur-unsur } \\
\text { desain busana }\end{array}$ & $\begin{array}{l}\text { - Apabila unsur desain sangat sesuai diterapkan } \\
\text { pada desain busana memiliki } 5 \text { kriteria, yaitu : } \\
\text { (1) Menerapkan unsur garis } \\
\text { (2) Menerapkan unsur bentuk } \\
\text { (3) Menerapkan unsur ukuran } \\
\text { (4) Menerapkan unsur warna } \\
\text { (5) Menerapkan unsur tekstur } \\
\text { - Apabila unsur desain sesuai diterapkan pada } \\
\text { desain busana memenuhi } 4 \text { kriteria di atas. } \\
\text { - Apabila unsur desain cukup sesuai diterapkan } \\
\text { pada desain busana memenuhi } 3 \text { kriteria di atas. } \\
\text { - Apabila unsur desain kurang sesuai diterapkan } \\
\text { pada desain busana memenuhi } 2 \text { kriteria di atas. } \\
\text { - Apabila unsur desain sangat kurang sesuai } \\
\text { diterapkan pada desain busana hanya memenuhi } \\
1 \text { kriteria di atas. }\end{array}$ & $\begin{array}{l}3 \\
2\end{array}$ \\
\hline & $\begin{array}{l}\text { c. Menerapkan } \\
\text { prinsip- } \\
\text { prinsip desain } \\
\text { busana }\end{array}$ & $\begin{array}{l}\text { - Apabila prinsip desain sangat sesuai diterapkan } \\
\text { pada desain busana memiliki } 5 \text { kriteria, yaitu : } \\
\text { (1) Menerapkan prinsip kesatuan } \\
\text { (2) Menerapkan prinsip perbandingan } \\
\text { (3) Menerapkan prinsip keseimbangan } \\
\text { (4) Menerapkan prinsip irama, } \\
\text { (5) Menerapkan prinsip pusat perhatian } \\
\text { - Apabila prinsip desain sesuai diterapkan pada } \\
\text { desain busana memenuhi } 4 \text { kriteria di atas. } \\
\text { - Apabila prinsip desain cukup sesuai diterapkan } \\
\text { pada desain busana memenuhi } 3 \text { kriteria di atas. }\end{array}$ & $\begin{array}{l}4 \\
3\end{array}$ \\
\hline
\end{tabular}




\begin{tabular}{|c|c|c|c|}
\hline & & $\begin{array}{l}\text { - Apabila prinsip desain kurang sesuai diterapkan } \\
\text { pada desain busana memenuhi } 2 \text { kriteria di atas. } \\
\text { - Apabila prinsip desain sangat kurang sesuai } \\
\text { diterapkan pada desain busana hanya memenuhi } \\
1 \text { kriteria di atas }\end{array}$ & 2 \\
\hline & $\begin{array}{llr}\text { d. Ada bagian } & \text { muka } \\
\text { belakang } & \end{array}$ & $\begin{array}{l}\text { - Apabila desain busana yang dibuat sangat jelas } \\
\text { dan proporsional memiliki } 5 \text { kriteria, yaitu : } \\
\text { (1) Desain bagian muka sesuai proporsi tubuh } \\
\text { (2) Desain bagian belakang sesuai proporsi tubuh } \\
\text { (3) Bagian-bagian muka digambar jelas } \\
\text { (4) Bagian lengan dan jari tangan digambar jelas } \\
\text { (5) Bagian kaki digambar jelas } \\
\text { - Apabila desain busana yang dibuat dengan jelas } \\
\text { dan proporsional memenuhi } 4 \text { kriteria di atas. } \\
\text { - Apabila desain busana yang dibuat cukup jelas } \\
\text { dan proporsional memenuhi } 3 \text { kriteria di atas. } \\
\text { - Apabila desain busana yang dibuat kurang jelas } \\
\text { dan proporsional memenuhi } 2 \text { kriteria di atas. } \\
\text { - Apabila desain busana yang dibuat sangat } \\
\text { kurang jelas dan proporsional hanya memenuhi } 1 \\
\text { kriteria di atas. }\end{array}$ & 5 \\
\hline \multirow[t]{2}{*}{$\begin{array}{l}\text { 2.Penyelesaian } \\
\text { Desain } \\
\text { Busana }\end{array}$} & $\begin{array}{l}\text { a. Menyelesaikan } \\
\text { desain busana } \\
\text { dengan } \\
\text { menggunakan } \\
\text { teknik kering }\end{array}$ & $\begin{array}{l}\text { - Apabila menyelesaikan desain busana } \\
\text { menggunakan teknik kering dilakukan sangat } \\
\text { cermat memiliki } 5 \text { kriteria, yaitu: } \\
\text { (1) Keharmonisan dalam pemilihan warna busana } \\
\text { dan warna kulit } \\
\text { (2) Menerapkan nilai gelap terang warna } \\
\text { (3) Bagian yang tertimpa cahaya dibuat lebih } \\
\text { terang } \\
\text { (4) Pewarnaan bahan dan permukaan tekstil } \\
\text { terlihat } \\
\text { (5) Pewarnaan detail-detail bagian busana jelas } \\
\text { - Apabila menyelesaikan desain busana } \\
\text { menggunakan teknik kering dilakukan dengan } \\
\text { cermat memiliki } 4 \text { kriteria di atas. } \\
\text { - Apabila menyelesaikan desain busana } \\
\text { menggunakan teknik kering dilakukan cukup } \\
\text { cermat memiliki } 3 \text { kriteria di atas. } \\
\text { - Apabila menyelesaikan desain busana } \\
\text { menggunakan teknik kering dilakukan kurang } \\
\text { cermat memiliki } 2 \text { kriteria diatas. } \\
\text { - Apabila menyelesaikan desain busana } \\
\text { menggunakan teknik kering dilakukan sangat } \\
\text { kurang cermat memiliki } 1 \text { kriteria diatas. }\end{array}$ & 5 \\
\hline & $\begin{array}{l}\text { b. Kerapihan pada } \\
\text { desain busana }\end{array}$ & $\begin{array}{l}\text { - Apabila penyelesaian desain busana dilakukan } \\
\text { sangat rapih memiliki } 5 \text { kriteria, yaitu : } \\
\text { (1) Goresan pensil menurut arah benang } \\
\text { (2) Mewarnai tidak melebihi garis luar (siluet) } \\
\text { (3) Pewarnaan rata sesuai tekniknya } \\
\text { (4) Tidak nampak garis pertolongan } \\
\text { (5) Pemakaian pensil tidak ditekan. } \\
\text { - Apabila penyelesaian desain busana dilakukan } \\
\text { dengan rapih memenuhi } 4 \text { kriteria di atas. } \\
\text { - Apabila penyelesaian desain busana dilakukan } \\
\text { cukup rapih memenuhi } 3 \text { kriteria di atas. }\end{array}$ & 5 \\
\hline
\end{tabular}




\begin{tabular}{|c|c|c|}
\hline & $\begin{array}{l}\text { - Apabila penyelesaian desain busana dilakukan } \\
\text { kurang rapih memenuhi } 2 \text { kriteria di atas. } \\
\text { - Apabila penyelesaian desain busana dilakukan } \\
\text { sangat kurang rapih hanya memenuhi } 1 \text { kriteria di } \\
\text { atas. }\end{array}$ & 2 \\
\hline $\begin{array}{l}\text { c.Penampilan } \\
\text { keseluruhan } \\
\text { (hasil desain } \\
\text { busana) }\end{array}$ & $\begin{array}{l}\text { - Apabila desain busana dibuat sangat sesuai } \\
\text { dengan pesanan konsumen memiliki } 5 \text { kriteria, } \\
\text { yaitu : } \\
\text { (1)Desain busana sesuai dengan proporsi tubuh. } \\
\text { (2) Adanya bagian yang tebal dan tipis sehingga } \\
\text { gambar busana kelihatan hidup } \\
\text { (3) Bagian kepala dan wajah digambar sesuai } \\
\text { proporsi } \\
\text { (4) Bagian tangan jelas } \\
\text { (5) Bagian kaki jelas } \\
\text { - Apabila desain busana dibuat sesuai dengan } \\
\text { pesanan konsumen memenuhi } 4 \text { kriteria di atas. } \\
\text { - Apabila desain busana dibuat cukup sesuai } \\
\text { dengan pesanan konsumen memenuhi } 3 \text { kriteria } \\
\text { di atas } \\
\text { - Apabila desain busana dibuat kurang sesuai } \\
\text { dengan pesanan konsumen memenuhi } 2 \text { kriteria } \\
\text { di atas } \\
\text { - Apabila desain busana dibuat sangat kurang } \\
\text { sesuai dengan pesanan konsumen hanya } \\
\text { memenuhi } 1 \text { kriteria di atas }\end{array}$ & 5 \\
\hline
\end{tabular}

\section{PEDOMAN PENILAIAN PORTOFOLIO MEMBUAT POLA BUSANA DENGAN TEKNIK KONSTRUKSI}

\begin{tabular}{|c|c|c|c|}
\hline Kompetensi & $\begin{array}{l}\text { Aspek yang } \\
\text { Dinilai }\end{array}$ & Kriteria Penilaian & Skor \\
\hline \multirow[t]{2}{*}{$\begin{array}{l}\text { 1. Menggambar } \\
\text { Pola }\end{array}$} & a. Ketepatan ukuran & $\begin{array}{l}\text { - Apabila pola dasar digambar dengan ukuran yang } \\
\text { sangat tepat memiliki } 5 \text { kriteria yaitu: } \\
\text { (1) Ketepatan ukuran lingkar badan } \\
\text { (2) Ketepatan ukuran lingkar pinggang } \\
\text { (3) Ketepatan ukuran lingkar panggul } \\
\text { (4) Ketepatan ukuran panjang punggung } \\
\text { (5) Ketepatan ukuran panjang muka } \\
\text { - Apabila pola dasar digambar dengan ukuran yang } \\
\text { tepat memenuhi } 4 \text { kriteria di atas } \\
\text { - Apabila pola dasar digambar dengan ukuran yang } \\
\text { cukup tepat memenuhi } 3 \text { kriteria di atas } \\
\text { - Apabila pola dasar digambar dengan ukuran yang } \\
\text { kurang tepat memenuhi } 2 \text { kriteria di atas } \\
\text { Apabila pola dasar digambar dengan ukuran yang } \\
\text { sangat kurang tepat hanya memenuhi } 1 \text { kriteria di } \\
\text { atas }\end{array}$ & $\begin{array}{l}4 \\
3 \\
2 \\
1\end{array}$ \\
\hline & $\begin{array}{l}\text { b.Kelengkapan } \\
\text { tanda-tanda pola }\end{array}$ & $\begin{array}{l}\text { - Apabila pola dasar digambar dengan garis dan tanda- } \\
\text { tanda pola yang sangat lengkap memilki } 5 \text { kriteria } \\
\text { yaitu : } \\
\text { (1) TM tepat diterapkan untuk keterangan pola dasar } \\
\text { Tengah Muka } \\
\text { (2) TB tepat diterapkan untuk keterangan pola dasar } \\
\text { Tengah Belakang } \\
\text { (3) (garis lurus warna merah) untuk garis } \\
\text { pola bagian muka }\end{array}$ & 5 \\
\hline
\end{tabular}




\begin{tabular}{|c|c|c|c|}
\hline & & 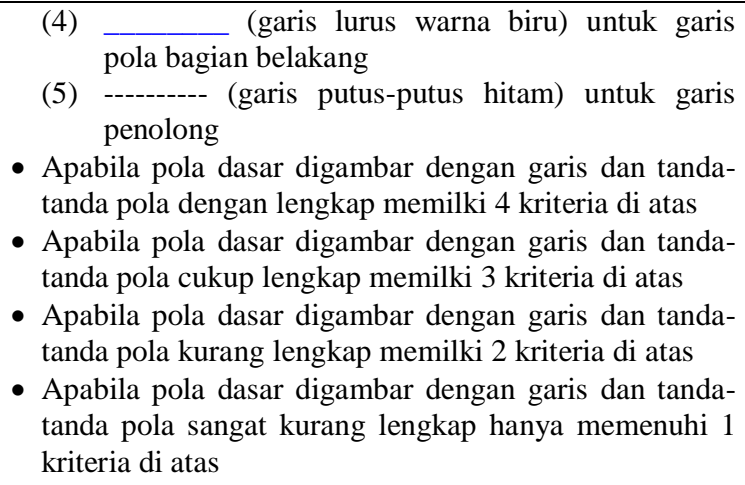 & 1 \\
\hline & c. Kerapihan & $\begin{array}{l}\text { - Apabila pola dasar digambar sangat rapih memiliki } 5 \\
\text { kriteria, yaitu: } \\
\text { (1) Pola dasar yang sudah dibuat dalam keadaan } \\
\text { bersih } \\
\text { (2) Pemberian warna merah dan biru tepat pada garis } \\
\text { pola } \\
\text { (3) Penulisan keterangan tanda pola tepat pada } \\
\text { tempatnya } \\
\text { (4) Garis penolong yang diperlukan sudah diberi } \\
\text { warna hitam dengan tepat } \\
\text { (5) Garis penolong yang tidak diperlukan sudah tidak } \\
\text { tampak } \\
\text { - Apabila pola dasar digambar dengan rapih memenuhi } 4 \\
\text { kriteria di atas } \\
\text { - Apabila pola dasar digambar cukup rapih memenuhi } 3 \\
\text { kriteria di atas } \\
\text { - Apabila pola dasar digambar kurang rapih memenuhi } 2 \\
\text { kriteria di atas } \\
\text { Apabila pola dasar digambar sangat kurang rapih } \\
\text { hanya memenuhi } 1 \text { kriteria di atas }\end{array}$ & 5 \\
\hline \multirow[t]{2}{*}{\begin{tabular}{l}
\multicolumn{2}{l}{ 2.Mengubah } \\
Pola sesuai \\
model
\end{tabular}} & $\begin{array}{l}\text { a.Menganalisis } \\
\text { model }\end{array}$ & $\begin{array}{l}\text { - Apabila model dinalisis sangat tepat memiliki } 5 \\
\text { kriteria, yaitu: } \\
\text { (1) Memahami jenis busana } \\
\text { (2) Memahami desain busana sesuai desempatan } \\
\text { (3) Memahami detail-detail busana sesuai model } \\
\text { (4) Memahami tekstur kain } \\
\text { (5) Memahami warna dan corak vahan } \\
\text { (6) Memami teknik penyelesaian busana } \\
\text { - Apabila model dinalisis dengan tepat memenuhi } 4 \\
\text { kriteria di atas } \\
\text { - Apabila model dinalisis cukup tepat memenuhi } 3 \\
\text { kriteria di atas } \\
\text { - Apabila model dinalisis kurang tepat memiliki } 2 \\
\text { kriteria di atas } \\
\text { - Apabila model dinalisis sangat kurang tepat hanya } \\
\text { memiliki } 1 \text { kriteria di atas }\end{array}$ & 1 \\
\hline & $\begin{array}{l}\text { b. Mengubah pola } \\
\text { sesuai model }\end{array}$ & $\begin{array}{l}\text { - Apabila perubahan pola digambar sangat rapih } \\
\text { memiliki } 5 \text { kriteria, yaitu: } \\
\text { (1) Pola dasar yang sudah dibuat dalam keadaan } \\
\text { bersih } \\
\text { (2) Pemberian warna merah dan biru tepat pada garis } \\
\text { pola } \\
\text { (3) Penulisan keterangan tanda pola tepat pada } \\
\text { tempatnya } \\
\text { (4) Garis penolong yang diperlukan sudah diberi } \\
\text { warna hitam dengan tepat } \\
\text { (5) Garis penolong yang tidak diperlukan sudah tidak } \\
\text { tampak }\end{array}$ & 5 \\
\hline
\end{tabular}




\begin{tabular}{|c|c|c|}
\hline & $\begin{array}{l}\text { - Apabila perubahan pola digambar dengan rapih } \\
\text { memiliki } 4 \text { kriteria } \\
\text { - Apabila perubahan pola digambar cukup rapih } \\
\text { memiliki } 3 \text { kriteria } \\
\text { - Apabila perubahan pola digambar kurang rapih } \\
\text { memiliki } 2 \text { kriteria } \\
\text { - Apabila perubahan pola digambar sangat kurang rapih } \\
\text { hanya memiliki } 1 \text { kriteria }\end{array}$ & 1 \\
\hline $\begin{array}{l}\text { c. Memberi tanda- } \\
\text { tanda pola }\end{array}$ & 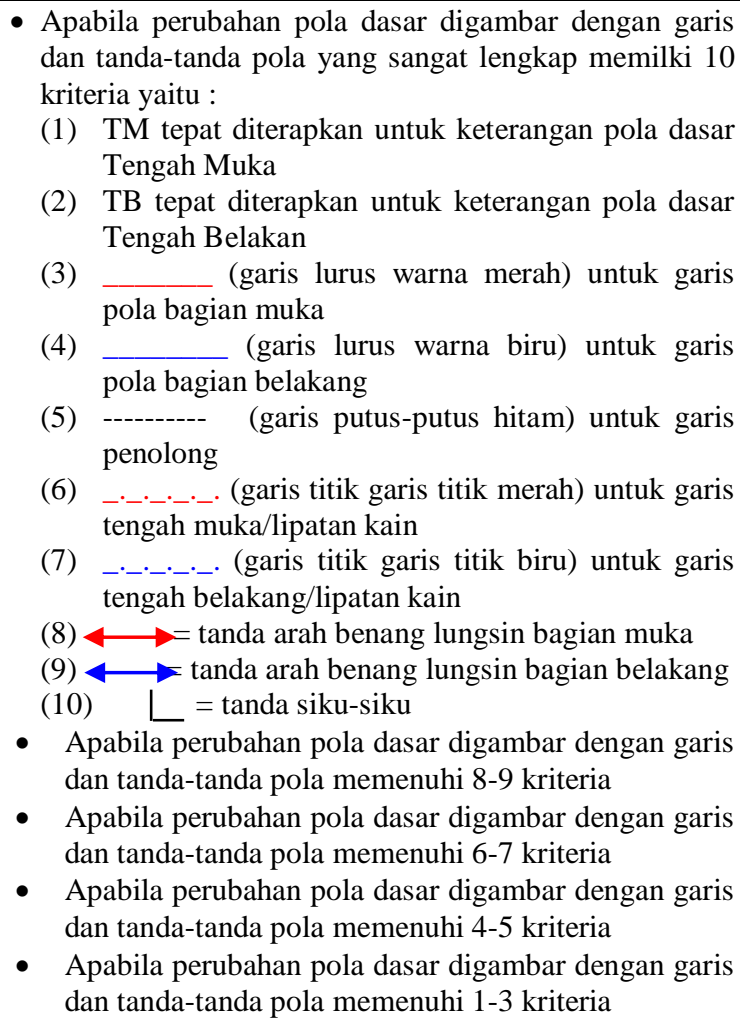 & 5 \\
\hline d. Kerapihan & $\begin{array}{l}\text { - Apabila gambar perubahan pola sangat rapih } \\
\text { memiliki } 5 \text { kriteria: } \\
\text { (1) Pola yang sudah dibuat dalam keadaan bersih } \\
\text { (2) Pemberian warna merah dan biru tepat pada } \\
\text { garis pola } \\
\text { (3) Penulisan keterangan tanda pola tepat pada } \\
\text { tempatnya } \\
\text { (4) Garis penolong yang diperlukan sudah diberi } \\
\text { warna hitam dengan tepat } \\
\text { (5) Garis penolong yang tidak diperlukan sudah } \\
\text { tidak tampak } \\
\text { - Apabila gambar perubahan pola tampak rapih } \\
\text { memenuhi } 4 \text { kriteria di atas } \\
\text { - Apabila gambar perubahan pola cukup rapih } \\
\text { memenuhi } 3 \text { kriteria di atas } \\
\text { - Apabila gambar perubahan pola kurang rapih } \\
\text { memenuhi } 2 \text { kriteria di atas } \\
\text { - Apabila gambar perubahan pola cukup rapih } \\
\text { memenuhi } 3 \text { kriteria di atas }\end{array}$ & $\begin{array}{l}2 \\
1\end{array}$ \\
\hline
\end{tabular}




\section{PEMBAHASAN}

Model Portfolio Based Assessment pada kompetensi kejuruan di SMK meliputi tahap perencanaan, pengembangan instrumen dan pelaksanaan penilaian. Model ini dirancang berdasarkan kajian teori dan hasil studi pendahuluan yang dilaksanakan pada beberapa SMK Program Keahlian Tata Busana di Kota dan Kabupaten Bandung. Tahapan yang dirancang pada model ini merujuk pada pengertian model dalam penilaian yang dideskripsikan Jubaedah (2009) sebagai berikut: "Seperangkat prosedur yang berurutan meliputi perencanaan penilaian, instrumen penilaian dan pelaksanaan penilaian untuk mewujudkan suatu proses dalam menentukan nilai kepada peserta didik berdasarkan suatu kriteria tertentu atau standar".

a. Perencanaan Penilaian

Pada tahap perencanaan penilaian mencakup komponen sebagai berikut:

1) Tujuan: Dirumuskan sesuai Standar Kompetensi meliputi kemampuan kognitif dan psikomotor dalam Menggambar Busana dan Membuat Pola dengan Teknik Konstruksi.

2) Materi Uji: Ditentukan sesuai kompetensi dasar

3) Metode Penilaian: Jenis penilaian (Tes tindakan), Bentuk penilaian (Produk kerja), Alat Penilaian (Tugas kerja dan Skala penilaian).

4) Jumlah Tugas: Disesuaikan dengan tingkat kesulitan materi uji

b. Pengembangan Instrumen Penilaian

Pada tahap pengembangan instrumen penilaian mencakup komponen sebagai berikut:

1. Penyusunan kisi-kisi instrumen penilaian

2. Penyusunan instrumen penilaian

3. Pengembangan kriteria penilaian

4. Uji kualitas instrumen penilaian

Tahapan pengembangan instrumen penilaiaan ini sejalan dengan hasil penelitian Budhyani (1999 : 68), yang mengungkapkan bahwa: "Pengembangan instrumen pengukuran keterampilan desain busana dengan menggunakan langkahlangkah pengembangan instrumen yang standar dan kisi-kisi yang digunakan tepat 
dapat menghasilkan instrumen pengukuran yang baik". Dari penelitian yang dilakukan, Budhyani (1999 : 68) menyimpulkan sebagai berikut :

Untuk mengembangkan instrumen pengukuran keterampilan desain busana dapat dilalui langkah-langkah, yaitu : a. Tahap pengembangan instrumen yang terdiri dari : 1) merumuskan tujuan pengukuran, 2) membuat kisi-kisi atau tabel spesifikasi, 3) membuat instrumen pengukuran, 4) membuat kriteria pengukuran, 5) membuat lembar pengamatan, dan 6) menelaah butir-butir instrumen dan kriteria pengukuran. b. Tahap uji coba, ... c. Tahap pelaporan hasil penelitian dengan mengadministrasikan instrumen pengukur keterampilan desain busana sesuai dengan aspek yang diukur untuk dijadikan tes tandar.

\section{c. Pelaksanaan Penilaian}

Pada tahap pelaksanaan penilaian mencakup komponen sebagai berikut:

1. Kemampuan kognitif: Pengetahuan, pemahaman, penerapan, analisis dan sintesis, evaluasi, kreasi

2. Kemampuan Psikomotor: Keterampilan teknis, kerapihan

Pedoman penilaian portofolio yang dikembangkan pada penelitian ini menghasilkan pedoman penilaian yang dilengkapi dengan kriteria penilaian untuk menilai portofolio Menggambar Busana dan Membuat Pola dengan Teknik Konstruksi. Pedoman dan kriteria penilaian dikembangkan mengacu pada standar kompetensi nasional bidang keahlian tata busana, yang telah dirumuskan sesuai dengan tuntutan kompetensi kerja di dunia usaha dan industri bidang busana. Sejalan dengan pendapat Evarinayanti (2002:6) yang mengungkapkan tentang standar kompetensi nasional, sebagai berikut :

- Standar kompetensi menetapkan spesifikasi dari pengetahuan, keterampilan, sikap dan atribut serta penerapannya sesuai dengan standar-standar kinerja yang dibutuhkan dalam pekerjaan.

- Standar kompetensi dikembangkan oleh industri berdasarkan pada struktur pekerjaan dalam industri tertentu

- Standar kompetensi selalu ditinjau kembali secara periodik untuk memastikan keterkaitannya dengan struktur pekerjaan industri 
Standar kompetensi nasional dikembangkan oleh pihak-pihak industri didasarkan pada standar atau patokan untuk pekerjaan sesuai tuntutan dunia usaha dan industri yang memiliki tujuan sebagai berikut :

a) Memberikan suatu cara bagi industri untuk menetapkan atau menentukan syarat-syarat apa yang dibutuhkan individu untuk dapat mengetahui dan melaksanakannya di tempat kerja.

b) Memberikan patokan bagi sistem pelatihan untuk mengembangkan dan menyajikan program pelatihan yang berhubungan dengan kebutuhan tempat kerja.

c) Memberikan patokan yang memastikan bahwa sistem tersebut meyakinkan menyampaikan apa yang diminta atau diinginkan industri atau perusahaan.

\section{KESIMPULAN}

Dari seluruh kegiatan penelitian yang telah dilakukan, maka dapat ditarik beberapa simpulan sebagai berikut:

1. Sekolah Menengah Kejuruan Program Keahlian Tata Busana sudah menerapkan penilaian berbasis portofolio melalui penilaian dokumen desain sebagai kumpulan tugas pada standar kompetensi Menggambar Busana dan penilaian dokumen pola konstruksi sebagai tugas pada standar kompetensi Membuat Pola dengan Teknik Konstruksi.

2. Jumlah tugas sebagai evidence peserta didik pada setiap Sekolah Menengah Kejuruan masih bervariasi, karena disesuaikan dengan fasilitas belajar dan karakteristik sekolah masing-masing.

3. Model Portfolio Based Assessment Pada Kompetensi Kejuruan di SMK yang difokuskan pada standar kompetensi Menggambar Busana dan Membuat Pola dengan Teknik Konstruksi; meliputi : a) Perencanaan penilaian, b) Pengembangan instrumen penilaian, c) Pelaksanaan penilaian.

4. Tahap perencanaan penilaian portofolio mencakup komponen tujuan, materi uji, metode penilaian dan jumlah evidence pada standar kompetensi Menggambar Busana dan Membuap Pola Busana dengan Teknik Konstruksi. 
5. Tahap pengembangan instrumen penilaian portofolio mencakup komponen: a) Penyusunan kisi-kisi instrumen penilaian, b) Penyusunan instrumen penilaian, c) Pengembangan kriteria penilaian, d) Uji kualitas instrumen penilaian

\section{DAFTAR PUSTAKA}

Budhyani, I.D.A.M. (1999). Pengembangan Instrumen Pengukuran Keterampilan Desain Busana Siswa Sekolah Menengah Kejuruan Jurusan Busana. Yogyakarta : Program Pascasarjana Institut Keguruan dan Ilmu Pendidikan.

Departemen Pendidikan Nasional. (2006). Petunjuk Teknis Penyusunan Perangkat Uji : Ujian Nasional Komponen Produktif dengan Pendekatan Project Work. Jakarta : Direktorat Pembinaan Sekolah Menengah Kejuruan.

Evarinayanti. (2002). Pelatihan Berbasis Kompetensi (Competency Based Training). Jakarta : Departemen Pendidikan Nasional.

Jubaedah, Y. (2009). Model Penilaian Keahlian Tata Busana Berbasis Standar Kompetensi Nasional di Sekolah Menengah Kejuruan. Bandung: Universitas Pendidikan Indonesia.

Jubaedah, Y. (2005). Telaah Implementasi Pendekatan Competency Based Training Berdasarkan Standar Kompetensi Nasional Pada Kegiatan Pembelajaran di Sekolah Menengah Kejuruan Kelompok Pariwisata. Bandung : Program Pascasarjana Universitas Pendidikan Indonesia.

Kuswari. (2009). Lulusan SMK Mau ke Mana ?. Terdapat di [On-line] http://pendis.depag.go.id/index.php?a=detilberita\&id=3169 (19 Agustus 2000 
